\title{
Development of a Passive Direct Methanol Fuel Cell Stack for Portable Applications
}

\author{
Takahiro SHIMIZU, ${ }^{\mathrm{a}, \mathrm{b}}$ Mohamed MoHAMEDI, ${ }^{\mathrm{a}, \mathrm{c}}$ Toshiyuki MommA, ${ }^{\mathrm{a}, \mathrm{b}}$ Tetsuya OSAKA ${ }^{\mathrm{a}}$ * \\ ${ }^{a}$ Graduate School of Science and Engineering, Waseda University (3-4-1 Okubo, Shinjuku-ku, Tokyo 169-8555, Japan) \\ ${ }^{\mathrm{b} C R E S T}$, Japan Science and Technology Agency (Tokyo 102-8666, Japan) \\ cPresent address: INRS-Centre Energie, Materiaux et Telecommunications, University of Quebec (1650, boul. Lionel \\ Boulet, Varennes (Quebec) J3X 1S2, Canada)
}

Received April 9, 2004 ; Accepted June 2, 2004

\begin{abstract}
In this work, we describe the fabrication of a room temperature operating direct methanol fuel cell (DMFC) device for portable electronic devices and its performance as an electrical power source for portable phone. The cell stack is completely passive without external pumps or other ancillary devices. It takes oxygen from the surrounding air, whereas the methanol solution is stored in a built-in reservoir. We achieved a maximum power as high as $2 \mathrm{~W}$, which is largely commensurate with cell phone requirements. The DMFC coupled to DC-to-DC converter was capable of powering a cell phone. The maximum power consumption for talk mode was of $1.2 \mathrm{~W}$ while $1.8 \mathrm{~W}$ was withdrawn from the stack when receiving a call.
\end{abstract}

Key Words : Direct Methanol Fuel Cell, Passive Fuel Cells, Ambient Temperature, Small-scale Application, Cellular Phone

\section{Introduction}

Tremendous interest and significant efforts in developing micro (sub-Watt) and portable $(1-20 \mathrm{~W})$ direct methanol fuel cell systems are being made by several organizations around the world. ${ }^{1-15}$ Portable electronic applications may be the first significant entry point for fuel cells into the commercial market. It is projected that small fuel cells will one day supply power for a broad range of consumer/portable products such as cellular phones, laptop computers, PDAs, portable camera, and electronics games. Among fuel cells, direct methanol fuel cell (DMFC) has been deemed as a potential substitution to conventional batteries for powering various microsystems or portable devices. Methanol is to a great extent easier to store and transport without auxiliary devices for intermediate fuel processing and fuel reforming steps which are required by hydrogen-oxygen fuel cells. As well, byproducts of DMFC are ecologically inoffensive $\mathrm{CO}_{2}$ and water.

Further key advantages of direct methanol fuel cell technology for portable applications are: room temperature startup, performance near ambient conditions, the use of a liquid fuel, system simplicity, i.e., air breathing mode of operation, and competitive cost. The fact that DMFC can operate at ambient temperature significantly reduces the thermal management challenges. ${ }^{8}$ Towards these purposes, our laboratory is currently developing a $1 \mathrm{~W}-2 \mathrm{~W}$ DMFC prototype targeted as a battery replacement in cellular phones. This work studied the design, fabrication, and performance evaluation of a passive DMFC stack for portable applications. The cell stack is completely passive with no external pumps or other ancillary devices. It takes oxygen from the surrounding air, whereas the methanol solution is stored in a built-in reservoir.

\section{Experimental}

Backing layers of anode and cathode consisted of a carbon paper (Toray) of $205 \mu \mathrm{m}$ in thickness, and a carbon paper Teflon coated (Electrochem) of $240 \mu \mathrm{m}$ in thickness, respectively. Slurry for the catalyst layer was prepared by dispersing carbon supported Pt-Ru (30.1 wt. $\% \mathrm{Pt}, 23.3 \mathrm{wt} . \% \mathrm{Ru}$ on Ketjen Black) for anode or carbon supported Pt (47.2 wt.\% on Vulcan XC72R) for cathode into a commercial $5 \mathrm{wt} \%$ Nafion solution (Aldrich) mixed with 12-dimethoxyethane (Wako). The resultant slurry was spread on the carbon papers by using the Doctor Blade tool. The catalyst loading amount was 2.5 $\mathrm{mg} / \mathrm{cm}^{2}$ for both electrodes. Subsequently, the coated carbon papers were dried at $80^{\circ} \mathrm{C}$ for $30 \mathrm{~min}$ and at $140^{\circ} \mathrm{C}$ for $1 \mathrm{hr}$ in the oven.

Nafion 112 membrane (thickness: $50 \mu \mathrm{m}$, equivalent weight $1100 \mathrm{meg} / \mathrm{g}$, ionic conductivity $0.083 \Omega^{-1} \mathrm{~cm}^{-1}$, Dupont) was pretreated by sequential immersion in boiling solution of 3 vol. $\% \mathrm{H}_{2} \mathrm{O}_{2}$, distilled water, boiling solution of $1 \mathrm{M} \mathrm{H}_{2} \mathrm{SO}_{4}$, and distilled water, where each step lasted for $1 \mathrm{~h}$.

The catalyzed electrodes for the anode and cathode respectively were positioned on both sides of the pretreated Nafion 112 and hot pressed at $135^{\circ} \mathrm{C}$ under 100 $\mathrm{kgf} / \mathrm{cm}^{2}$ for $5 \mathrm{~min}$ to form a unit of MEA. The performance of the DMFC was tested by measuring its voltagecurrent characteristics with a Hokuto Denko Potentiostat/Galvanostat HA-501G. 


\section{Results and Discussion}

\section{1 Single cell design and performance}

A single $36 \mathrm{~cm}^{2}$ DMFC was designed and is shown in Fig. 1. A methanol reservoir was constructed out of Poly (methyl methacrylate) (PMMA) and silicone rubber. A gold-plated stainless steel (SUS) mesh sheet of $0.5 \mathrm{~mm}$ thickness with an open area of $20 \%$ was used on both anode and cathode sides. A square opening having a 36 $\mathrm{cm}^{2}$ geometric area was performed on the acryl end-plate cathode side. The cathode is thus in direct contact with air allowing passive and full self-breathing operation of the fuel cell. The oxygen from air will flow by natural convection through the perforated current collector and reaches the cathode. The important advantage of the open cathode is that additional ventilation by fans is not required. The dimensions of the methanol reservoir are $60 \mathrm{~mm}$ wide, $60 \mathrm{~mm}$ high, and $8 \mathrm{~mm}$ deep. Approximately $28 \mathrm{ml}$ of liquid methanol fuel solution were injected into the fuel reservoir using a syringe. Therefore, the entire DMFC is a pump-less operation and selfactivated by electrochemical reactions. All the components of the small DMFC that are shown in Fig. 1a were machined and put together using bolts on the four corners of the cell as pictured in Fig. $1 b$.

Figure 2, shows the results of a single cell polarization at room temperature and for three methanol concentrations. The voltage-current measurements were started after the methanol solution was poured in the cell for 30 minutes. Each data point represents typical steady state voltages that were taken after continuous operation for 3 min at the indicated current density. As can be seen from Fig. 2, the polarization curves exhibit kinetic and ohmic control, while the mass transport limitation is not apparent. In terms of output current, the performance at all values of cell voltage increased with methanol concentration. The open circuit voltage of $c a .0 .48 \mathrm{~V} \mathrm{did} \mathrm{not} \mathrm{sig-}$ nificantly change with methanol concentration indicating no methanol crossover effect up to $2 \mathrm{M}$ methanol concentration. The maximum power density as shown in Fig. 2 is $1.15 \mathrm{~mW} / \mathrm{cm}^{2}$ at a voltage of $0.28 \mathrm{~V}$ with $0.5 \mathrm{M}$ methanol, $1.9 \mathrm{~mW} / \mathrm{cm}^{2}$ at $0.24 \mathrm{~V}$ with $1.0 \mathrm{M}$ methanol, and $2.74 \mathrm{~mW} / \mathrm{cm}^{2}$ at $0.21 \mathrm{~V}$ with $2.0 \mathrm{M}$ methanol concentration. This trend demonstrates that the maximum power density more than doubles when the methanol concentration is increased from $0.5 \mathrm{M}$ to $2.0 \mathrm{M}$.
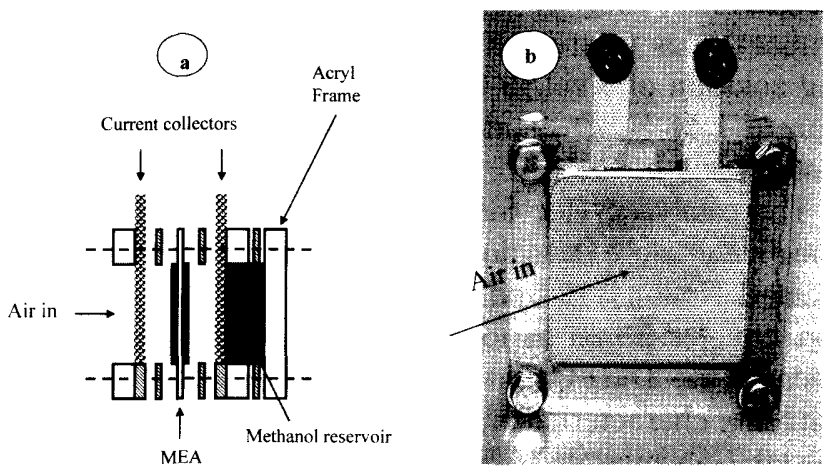

Fig. 1 The small air passive direct methanol fuel single cell. (a) Design, and (b) fabricated. Active area $36 \mathrm{~cm}^{2}$.

\section{2 Stack performance}

We determined that more than twenty individual cells would be required for the purpose of obtaining output power between 1 and $2 \mathrm{~W}$. A stack consisting of twenty cells in series has been built in. The active area of each cell is $36 \mathrm{~cm}^{2}$. The stack is provided with oxygen from the surrounding air to the open cathode sides. Figure 3 shows the open circuit voltage (OCV) of each cell at the three methanol concentrations considered. Uniform performance of individual cells can be seen; the OCV of each cell is close to $c a .0 .5 \mathrm{~V}$.

The performance of the DMFC stack current polarization is displayed in Fig. 4. Cell voltage versus current is displayed in Fig. 4a whereas Fig. 4b shows the dependence of power on current. Similar to the trend observed with the single cell, in terms of output current, the performance of the DMFC stack at all values of cell potential increased with methanol concentration.

Furthermore, the results of Fig. 4 demonstrates that the performance achieved from the twenty-cell stack un-

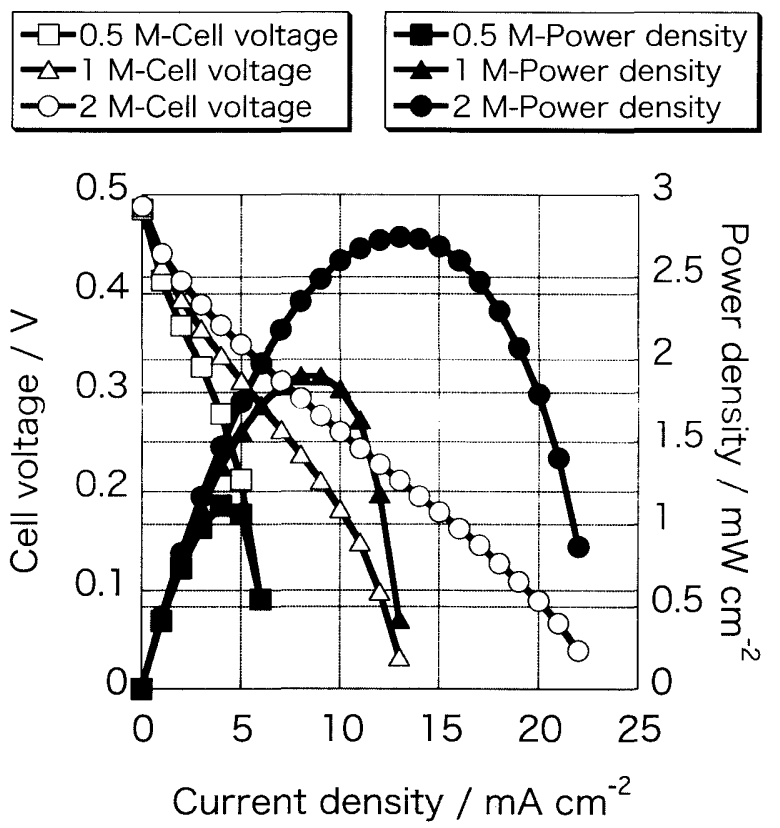

Fig. 2 Effect methanol concentration on performance of 36 $\mathrm{cm}^{2}$ area DMFC. Catalysts: carbon supported $\mathrm{Pt} / \mathrm{Ru}$ anode and carbon supported Pt cathode, current collector: SUS/Au, air passive, room temperature, and Nafion 112 . The catalyst loading amount was $2.5 \mathrm{mg} / \mathrm{cm}^{2}$ for both anode and cathode.

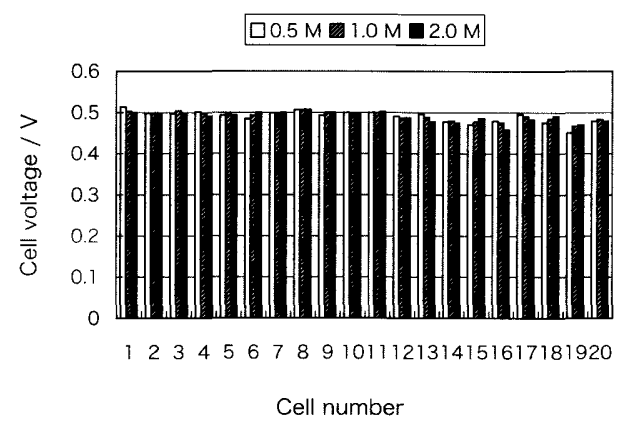

Fig. 3 Open circuit voltage (OCV) of individual cell at three methanol concentrations as indicated on the plot. 

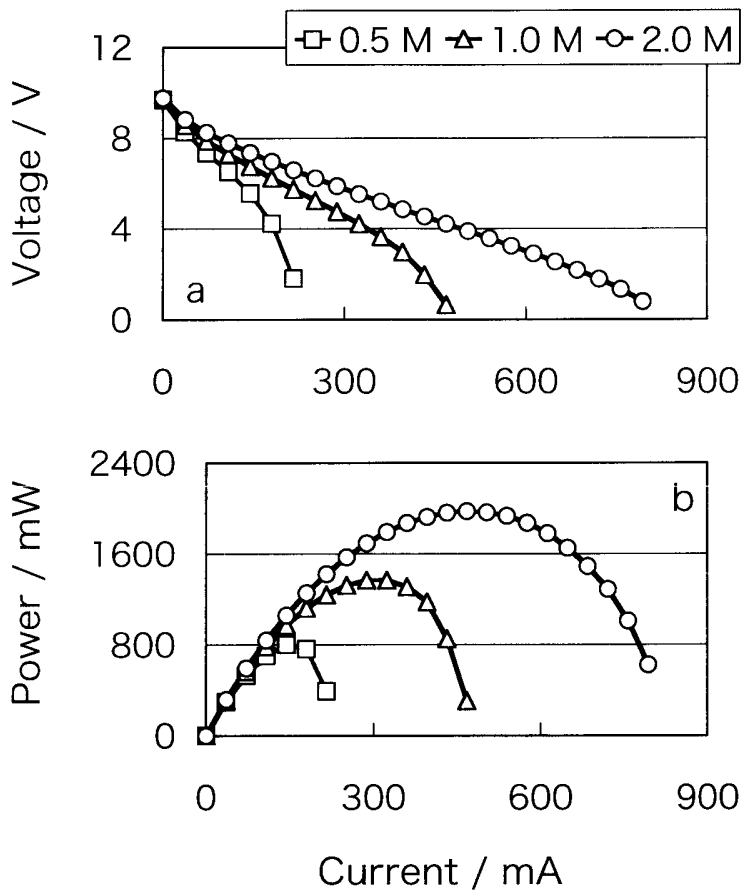

Fig. 4 Performance of the twenty-cell DMFC stack versus methanol concentration up to $2 \mathrm{M}$. (a) Polarization, and (b) power curves. Air passive, room temperature operation. The catalyst loading amount was $2.5 \mathrm{mg} / \mathrm{cm}^{2}$ for both anode and cathode.

der conditions which are relevant to portable application, in terms of voltage-current and power-current characteristics. The maximum power output generated by the stack under these conditions was, $803 \mathrm{~mW}$ at $5.57 \mathrm{~V}$, $1368 \mathrm{~mW}$ at $4.75 \mathrm{~V} 1975 \mathrm{~mW}$ at $4.22 \mathrm{~V}$, with $0.5 \mathrm{M}, 1.0$ $\mathrm{M}$, and $2.0 \mathrm{M}$ methanol concentration, respectively. The output power of the stack tested here is higher than $1 \mathrm{~W}$ for methanol concentration exceeding $0.5 \mathrm{M}$. Since about $1 \mathrm{~W}$ and $3.7-3.8 \mathrm{~V}$ are requested to operate a cellular phone, it is possible to operate a cellular phone with this stack.

Owing to the deleterious effect of methanol crossover, dilute methanol solutions (i.e. $1 \mathrm{M}$ ) were typically used in DMFC. However, under these conditions there will be likely insufficient fuel to create power. Thus it would be desirable to operate with a methanol concentration just above the minimum necessary to provide methanol to the anode. Meyers and Maynard ${ }^{12)}$ propose an optimal operating concentration of about $2 \mathrm{M}$ methanol.

The DMFC stack fed with $2 \mathrm{M}$ methanol concentration was connected in series to a cellular phone (NTT DoCoMo D209i) via a DC-to-DC converter. The DC-to-DC converter takes power from the stack and delivers it at constant specified voltage to all system components. The voltage was fixed to $3.7 \mathrm{~V}$ after DC-to-DC conversion and the cellular phone was operated for $5 \mathrm{~min}$. Figure 5 shows the current level after DC conversion when placing or receiving a phone call. The power required in both cases was calculated from the delivered current after DC conversion. The maximum power consumption for talk mode was of $1.2 \mathrm{~W}$ while $1.8 \mathrm{~W}$ is required when receiving a call.

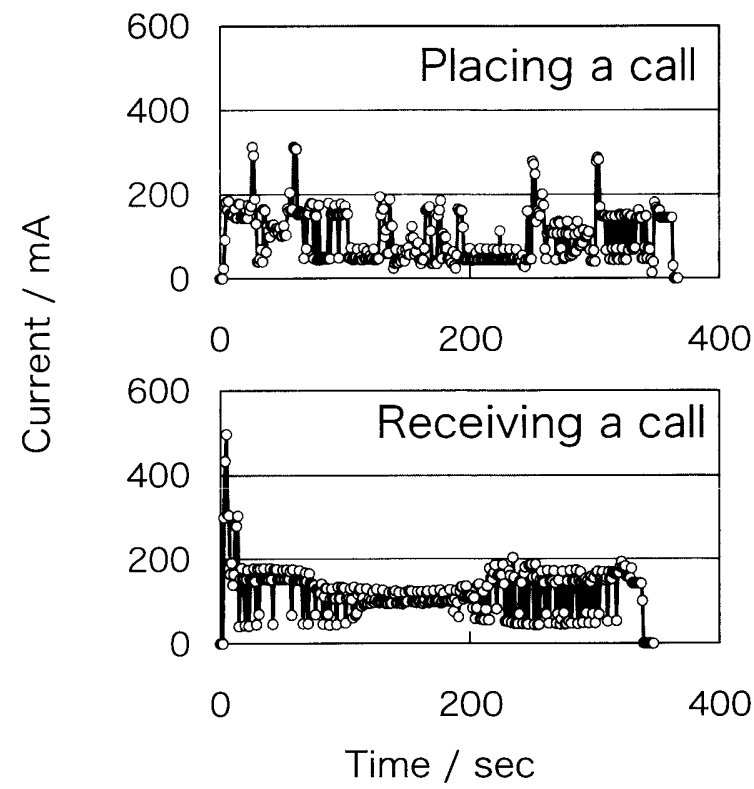

Fig. 5 The current level after dc conversion when placing or receiving a phone call using the twenty-cell DMFC stack. The operated cell phone was an NTT DoCoMo D209i. Operating conditions: $2 \mathrm{M}$ methanol concentration, air passive, and room temperature. The power consumption calculated from the delivered current after DC conversion was $1.2 \mathrm{~W}$ and 1.8 $\mathrm{W}$ for making a call and receiving a call, respectively.

\section{Conclusions}

The passive direct methanol fuel cell intended for room temperature operation was designed and constructed and its performances were tested. The DMFC stack composed with 20 cells connected in series is a stand-alone system with no external pumps or other ancillary devices. We achieved a maximum power as high as $2 \mathrm{~W}$, which is largely adequate with cell phone requirements. The DMFC coupled to DC-to-DC converter was capable of powering a cell phone.

The laboratory aims further to improve the performance of this DMFC system and to establish the assembling technique for practical applications. Some of the remaining challenges include system integration, tight packaging, and manufacturing costs.

\section{Acknowledgements}

The present work was partly supported by Grants-inaid for Scientific Research on Priority Area (B) "New Technologies of DMFC" (No. 13134204), COE Research "Molecular Nano-Engineering", and 21 COE Program "Practical Nano-Chemistry" from the Ministry of Education, Culture, Sports, Science and Technology (MEXT) of Japan.

\section{References}

1) S. C. Kelly, G. A. Deluga, and W. H. Smyrl, Electrochem Solid-State Lett., 3, 407 (2000).

2) S. C. Kelly, G. A. Deluga, and W. H. Smyrl, AIChE Journal, 48, 1071 (2002).

3) J. S. Wainright, R. F. Savinell, C. C. Liu, and M. Litt, 
Electrochim. Acta, 48, 2869 (2003).

4) R. Dillon, S. Srinivasan, A. S. Arico, and V. Antonucci, J. Power Sources, 127, 112 (2004).

5) G. Q. Lu, C. Y. Wang, T. J. Yen, and X. Zhang, Electrochim. Acta, 49, 821 (2004).

6) Y. Ho Seo and Y-H Cho, IEEE Proceedings of The Sixteenth Annual International Conference on Micro Electro Mechanical Systems, 19-23, 375 (2003).

7) M. M. Mench, Z. H. Wang, K. Bhatia, and C. Y. Wang, Proceedings of the IMECE'O1, Inter. Mech. Eng. Congress and Exposition (IMECE), (New-York), Nov. 11-16 (2001).

8) T. J. Yen, N. Fang, X. Zhang, G. Q. Lu, and C. Y. Wang, Appl. Phys. Lett., 83, 4056 (2003).
9) C. K. Dyer, Sci. Am., 281, 88 (1999).

10) S. C. Barton, T. Patterson, E. Wang, T. F. Fuller, and A. C. West, J. Power Sources, 96, 329 (2001).

11) M. A. Priestnall, V. P. Kotzeva, D. J. Fish, and E. M. Nilsson, J. Power Sources, 106, 21 (2002).

12) J. P. Meyers and H. L. Maynard, J. Power Sources, 109, 76 (2002).

13) H. L. Maynard and J. P. Meyers, J. Vac. Sci. Technol. B, 20, 1287 (2002).

14) S. R. Narayanan, T. I. Valdez, and F. Clara, The Electrochemical Society Proceedings, 2001-4, 254 (2001).

15) W. Y. Sim, G. Y. Kim, and S. S. Yang, IEEE Proceedings of the International Conference on Micro Electro Mechanical Systems, 341 (2001). 